\title{
Stress-induced changes in the gastrointestinal motor system
}

\author{
Victor Plourde MD PhD
}

V Plourde. Stress-induced changes in the gastrointestinal motor system. Can J Gastroenterol 1999;13(Suppl A):26A-31A. Several autonomic, hormonal, behavioural and neuropeptidergic bodily responses to stressful stimuli have been described over the past few decades. Both animal models and human paradigms have been explored. It is acknowledged that stress modulates gastrointestinal (GI) motility through central mechanisms including corticotropin-releasing-factor. This process requires the integrity of autonomic neural pathways. It has become evident that the effects of stress on GI motility vary according to the stressful stimulus, its intensity, the animal species under study and the time course of the study. Recent evidence suggests that chronic or possibly permanent changes develop in enteric smooth muscle properties in response to stress. In animals, the most consistent findings include retardation of gastric emptying in response to various stressors; acceleration of gastric emptying upon cold stress, presumably through the secretion of brain thyroglobulin-hormone; acceleration of intestinal transit; and stimulation of colonic transit and fecal output. In humans, the cold water immersion test has been associated with an inhibition of gastric emptying, while labyrinthine stimulation induces the transition from postprandial to fasting motor patterns in the stomach and the small bowel. Psychological stress has been shown to induce a reduction in the number and amplitude of intestinal migrating motor complexes and to neither affect nor stimulate colonic motility. These various responses to stress are presumably attributed to the preferential activation of specific neuronal pathways under the influence of a given stimulus or its intensity. The significance of these findings and the directions of further studies are discussed.

Key Words: Corticotropin-releasing factor, Gastrointestinal motor system, Irritable bowel syndrome, Stress

\section{Anomalies provoquées par le stress dans le système moteur gastro-intestinal}

RÉSUMÉ : Plusieurs réactions autonomes hormonales, comportementales et neuropeptidergiques de l'organisme face à des stimuli stressants ont été décrits depuis quelques décennies. Des études ont porté sur des modèles animaux et des paradigmes humains. On reconnaît que le stress influe sur la motilité gastro-intestinale par l'entremise de mécanismes centraux, notamment liés aux facteurs de la corticolibérine. Ce processus repose sur l'intégrité des voies neurales autonomes. On se rend compte que les effets du stress sur la motilité GI varie selon le type de stress, son intensité, l'espèce animale étudiée et le stade de l'étude. Selon de récents résultats, le stress entraînerait des anomalies chroniques et probablement permanentes des propriétés du muscle lisse entérique. Chez l'animal, les résultats les plus souvent observés sont le retard de la vidange gastrique en réponse à divers facteurs de stress, l'accélération de la vidange gastrique sous l'effet du froid, présumément par la sécrétion de l'hormone cérébrale thyroglobuline, l'accélération du transit intestinal et la stimulation du transit colonique et de l'émission de selles. Chez l'être humain, le test d'immersion dans l'eau froide a été associé à une inhibition de la vidange gastrique, alors que la stimulation labyrinthique entraîne un passage des modes moteurs post-prandiaux à des modes à préprandiaux dans l'estomac et l'intestin grêle. Le stress psychologique s'est révélé apte à provoquer une réduction du nombre et de l'importance des complexes moteurs migratoires intestinaux, sans affecter, ni stimuler la motilité colonique. Ces diverses réactions au stress sont présumément attribuées à l'activation préférentielle de certaines voies neuronales spécifiques sous l'influence d'un stimulus donné ou de son intensité. La portée de ces observations et l'orientation des études à venir sont présentées ici.
$\mathrm{T}$ he following definition of stress, provided by Hans Selye in 1950 (1), is the broadest and probably simplest definition: "Stress is the nonspecific response of an organism to perturbations of its environment". From this definition of stress, it is understood that a stressor that is stressful to one organism may not be stressful to another and that what is stressful to an organism at one time may not be stressful to the same organism at another time. As a complement to this 
COPYRIGHT PULSUS GROUP

definition, the French physiologist Claude Bernard suggested the concept of consistency of the interior milieu. According to his theory, an organism must make appropriate hormonal, autonomic and/or behavioural changes to retain homeostasis when it is subjected to a real or perceived threat or challenge. This challenge may be either physical or psychological. According to these definitions, a stressful situation or stimulus may be any physical, psychological, actual or perceived situation capable of inducing changes in normal homeostasis. In response to this change, the organism has to adapt, and these adaptive changes are the biological response to stress.

\section{STRESS, GUT MOTOR ACTIVITY AND TRANSMITTERS (HISTORICAL PERSPECTIVES)}

It was first observed by Beaumont in 1833 (2), from studies of St Martin's gastric fistula, that fear or anger subjectively decreases motor activity in the stomach. This anecdotal observation has been confirmed in more recent years by quantitative techniques demonstrating a delay in gastric emptying in response to stress (3). In animals, Hans Selye (4) established in 1936 that the stomach is an important target organ adversely affected by various stressors. He also observed that noxious treatments produced hypertrophy of the adrenal cortex in intact animals but not in hypophysectomized rats, suggesting a role of adrenocorticotrophic hormone $(\mathrm{ACTH})$ in this response. Harris (5) postulated in 1937 that a chemical transmitter in the hypothalamus may regulate the pituitary release of ACTH. In 1955, Guillemin and Rosenberg (6) demonstrated in vitro that hypothalamic extracts evoke the release of ACTH from the pituitary gland, and the existence of hypothalamic corticotropin-releasing hormone (CRF) was proposed. This transmitter was finally structurally characterized from sheep (7) as well as from other species, including humans (8).

\section{STRESS AND GASTROINTESTINAL MOTILITY Experiments in humans}

Pain stress (cold water stress) - Experimental procedure: Cold water stress (CWS) involves repeated nondominant hand immersion in ice water $\left(4^{\circ} \mathrm{C}\right)$ for 15 to 20 mins. On a separate occasion, subjects receive control stimulation consisting of repeated immersion of the same hand in warm water. This technique offers an inexpensive, simple, reproducible and controllable method of stressful stimulation. Furthermore, although the procedure may be unpleasant, it is not associated with any degree of physical harm. Gastric emptying of a standard liquid test meal containing ${ }^{14} \mathrm{C}$-polyethylene glycol was markedly delayed by the test stimulus; the reduction in meal emptying was $32 \pm 13 \mathrm{~mL}$ (mean \pm SE) during the 20 min stimulation period (3). This gastric stasis was best explained by an inhibition of gastric tone or by pyloric closure because there was no accompanying increase in duodenal motor activity to indicate an increased breaking effect on gastric emptying. Likewise, it has

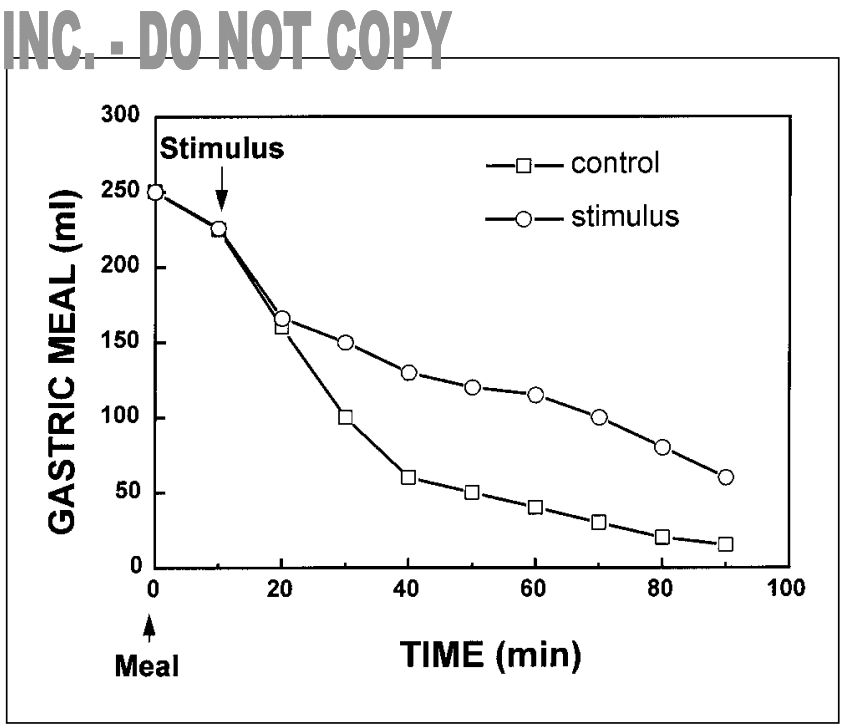

Figure 1) Effect of labyrinthine stimulation on gastric emptying of a nutritive meal. Reproduced with permission from reference 3

been shown that small intestinal transit was also delayed in response to CWS (9). However, the CWS test does not seem to influence colonic motor activity, at least in patients with irritable bowel syndrome (IBS) (10).

Significance: CWS is a standard and classical stress test according to the well established effects of stress on gastrointestinal (GI) motor function. It is not clear, however, whether CWS influences colonic motor function. It is possible that CWS induces a degree of autonomic arousal that is less than that experienced in stressful situations or life events encountered by IBS patients. This may explain in part why CWS was not shown to be capable of increasing colonic motor activity in such patients.

Labyrinthine stimulation - Experimental procedure: Labyrinthine stimulation at subnauseant levels is produced by instilling water at $4^{\circ} \mathrm{C}$ into the external auditory meatus of one ear at a rate of $1 \mathrm{~mL} / \mathrm{s}$ until a definite sensation of rotation is experienced. This procedure induces changes in motor activity through the stimulation of labyrinthic structures; instillation of warm water $\left(37^{\circ} \mathrm{C}\right)$ fails to produce vertigo or an effect on GI motility. As with CWS, labyrinthine stimulation was associated with a delay in gastric emptying through a decrease in antral contractions (Figure 1) (11). Furthermore, labyrinthine stimulation induced a change in the normal postprandial gastric motor pattern to a typical fasting pattern, with the appearance of aborally migrating bursts of contractions in the distal stomach and proximal duodenum (3).

Significance: The observed effect of stress from labyrinthine stimulation is thought to be a centrally mediated effect of the central nervous system on the gut because the stimulus acts directly on brain structures. The striking conversion of a fed to a fasting-like pattern despite the presence of food in the stomach raises the possibility that the central stimulus may actually disconnect the brain from the gut, thus precluding perception or reaction to luminal nutrients.

Psychological stress - Experimental procedure: Dichotomous listening, repetitive mental arithmetic problems, repet- 


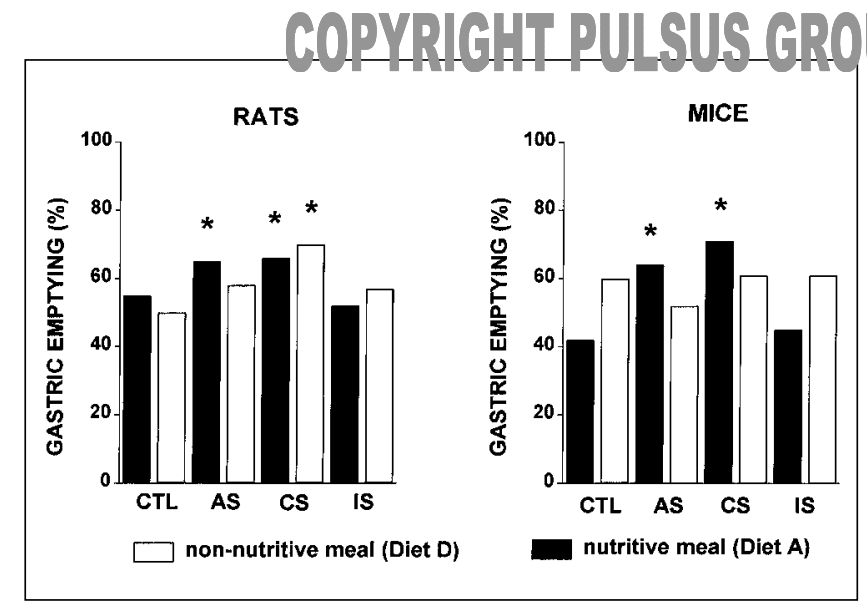

Figure 2) Effects of acoustic stress (AS), cold stress (CS) and immobilization stress (IS) on gastric emptying of nutritive (milk) versus non-nutritive (methyl-cellulose) meal in mice and rats. ${ }^{*} P<0.05$. CTL Control. Reproduced with permission from reference 18

itive hourly awakenings at night associated with mental tasks, delayed acoustic feedback, noise, sudden awakening at night, stressful interviews and video games are the main paradigms used to reproduce psychological stress in humans. Using dichotomous listening, McRae et al (12) observed that stress induced an inhibition of migrating motor complex (MMC) activity, although this inhibition faded when exposure to the stressor continued for a further $2 \mathrm{~h}$, suggesting an adaptation process of the small bowel in response to stress. To address this possibility, subjects were studied continuously for $48 \mathrm{~h}$, including two $8 \mathrm{~h}$ days under fasting conditions. The test group had one day without stress but on the second day were subjected to three different psychological stressors for $2 \mathrm{~h}$ each. During the second night, members of the test group were woken at $1 \mathrm{~h}$ intervals between 24:00 and 5:00 by bright lights and loud music, which were extinguished when the subjects keyed the correct answers to simple mental arithmetic problems into the keyboard of the computer controlling the sound and light. The results in the test group showed a consistent reduction in the number and amplitude of MMCs in the jejunum recorded in the test group during the $8 \mathrm{~h}$ stress period, compared with the same period on the previous day when no stressors were applied. The nocturnal stress, on the other hand, had only a slight influence on the incidence of MMCs. The modulation of MMCs by psychological stress was further investigated by Delis et al (13), who demonstrated that the reduction in amplitude of MMCs observed in response to stress was totally restored by trimebutine, a gut-selective enkephalinergic agonist. Again, no effect was observed on the appearance of the MMCs. The effect of noise on colonic motility was investigated by Erckenbrecht (14), who showed that stool weight as well as motility index in the sigmoid colon were significantly increased in response to stress. Likewise, Bassotti et al (15) and Almy (16) reported a significant increase in colonic motility index in response to sudden awakening at night. The results of these experiments agree with those of previous reports on colonic motility showing a tremendous increment in sigmoid motility in re-

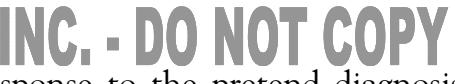

sponse to the pretend diagnosis of colonic cancer during colonoscopy in medical school students (15).

Significance: Compelling evidence has accumulated to suggest that stress may induce an alteration of intestinal MMCs. How the alteration of intestinal MMCs further influences symptomatic expression is a rather difficult question. However, the restoration of MMCs by a kappa agonist is interesting and provides further evidence of opioid pathways that are preferentially activated in response to stress. According to Delis et al (13), this observation may provide a biological substratum to explain the beneficial effects of trimebutine in IBS patients. Still, small bowel MMCs are characteristic of the fasting period, while IBS symptoms occur predominantly in response to meals. It is possible, however, that the dysfunction observed in IBS patients extends far beyond the postprandial period and, thus, well into the fasting period. In this regard, it may be possible to influence IBS postprandial symptoms through pharmacological modulation of the fasting period.

\section{Animal models}

Wrap restraint stress: Unanesthetized rats are partially restrained by wrapping the foreshoulders and thorax with paper tape (wrap restraint), and allowing the animal to move its hind limbs. This induces a form of psychological stress, and its effects on GI motility can be observed. Wrap restraint stress did not to influence gastric emptying of a non-nutrient solution (17).

Immobilization stress: Immobilization stress is produced by enclosing animals in a flexible tube $(3 \times 3 \mathrm{~mm})$ initially formed into a cone and bent to conform to the size of individual animals. According to Gué et al (18), immobilization stress does not seem to influence the emptying of a non-nutritive solution in mice and in rats (Figure 2).

Acoustic stress: Acoustic stress is produced by placing the animals in a closed box equipped with loudspeakers playing broad frequency taped music at room temperature $\left(20 \pm 2^{\circ} \mathrm{C}\right)$. Under such circumstances, it has been demonstrated that acoustic stress enhances the emptying of a non-nutritive solution in both mice and rats (19). The effects of acoustic stress on smooth muscle and enteric nerve function were also examined in vitro by Collins et al (20), who showed that the carbachol-induced contractile response was significantly greater in rats submitted to acoustic stress for four days. This hyperresponsiveness was totally reversible after one day without stress exposure if stress was applied for two days but was irreversible if stress was applied for more than two days. However, stress had no effect on ${ }^{3} \mathrm{H}$-acetylcholine release from the myenteric plexus.

Cold exposure stress: Cold exposure stress is produced by lowering the box temperature in which the animals are placed to $10 \pm 1^{\circ} \mathrm{C}$. Cold exposure stress was associated with an increase in the gastric emptying of a non-nutritive solution as well as of a nutritive solution, and this increase occurs both in mice and in rats $(18,19)$. On the other hand, cold exposure stress associated with immobilization induced a delay in the gastric emptying of a non-nutritive solution in rats 
COPYRIGHT PULSUS GROUP

$(17,21)$. It is also worth mentioning that the effect of cold restraint is associated with an initial increase in gastric emptying followed by a stabilization period and finally an actual retardation of emptying (third hour of stress) (21).

Modified passive avoidance test: The modified passive avoidance test is based on a conditioning period in which rats 'learn' to eat their meal in 30 mins by progressively reducing their daily access to food over seven days. On the day of the experiments, animals are placed in a plexiglass cage measuring $2500 \mathrm{~cm}^{3}$ filled with $500 \mathrm{~mL}$ of water at body temperature. The passive avoidance situation allows the rat to avoid contact with the water by climbing onto a glass block measuring $3 \times 4 \times 5 \mathrm{~cm}$. In control experiments, the box did not contain water. Using this experimental paradigm, Enck et al $(22,23)$ demonstrated that gastric emptying (percentage of food consumed) was significantly delayed, orocecal transit time was accelerated from 131 to 86 mins (breath hydrogen exhalation after the food had been labelled with $1 \mathrm{~g}$ of lactose) and colonic transit (measured by administering a carmine red solution into the cecum via a chronically implanted catheter) decreased from $13.9 \mathrm{~h}$ to $1.25 \mathrm{~h}$ in response to the modified passive avoidance test (Figure 3).

\section{MECHANISMS}

From pioneering studies by Selye $(1,4)$ suggesting that ACTH is secreted under the influence of stress, CRF was further structurally characterized and shown to be capable of reproducing most of the autonomic, behavioural and visceral effects of stress. Consequently, CRF was hypothesized to be the most important mediator of the GI effects of stress. It was further demonstrated that centrally administered CRF inhibits gastric emptying in rats and suppresses the gastric cyclic MMCs by replacing them with small amplitude, irregular contractions (24). It was also shown by Garrick et al $(25,26)$ that intracisternal administration of CRF inhibits the stimulating effect of the thyroglobulin hormone (TRH) analogue RX77368. In inhibiting gastric emptying, CRF acts through vagal efferents; vagotomy totally abolishes the effects of stress or CRF on gastric motor function (27). In rats, intracisternal injection of CRF was associated with a decrease in small bowel transit time and enhanced colonic transit time and fecal output $(27,28)$. Other possible peripheral mechanisms regulating GI motor activity under stressful conditions include alteration of the parasympathetic system, activation of the sympathetic nervous system, stimulation of the pituitary-adrenal axis, and release of opioid substances, pancreatic polypeptide and gastrin (29). While both neural and hormonal mechanisms are probably involved, the rapid onset of changes in GI motility in response to stress favours a predominant and direct neurally mediated mechanism.

\section{RELEVANCE OF THESE MODELS AND BIOLOGICAL SIGNIFICANCE}

Many stress models have been tested in rats to determine the effects of stress on GI motility. By extrapolating mechanisms from animals to humans, investigators have studied various experimental paradigms that to some extent relate to human

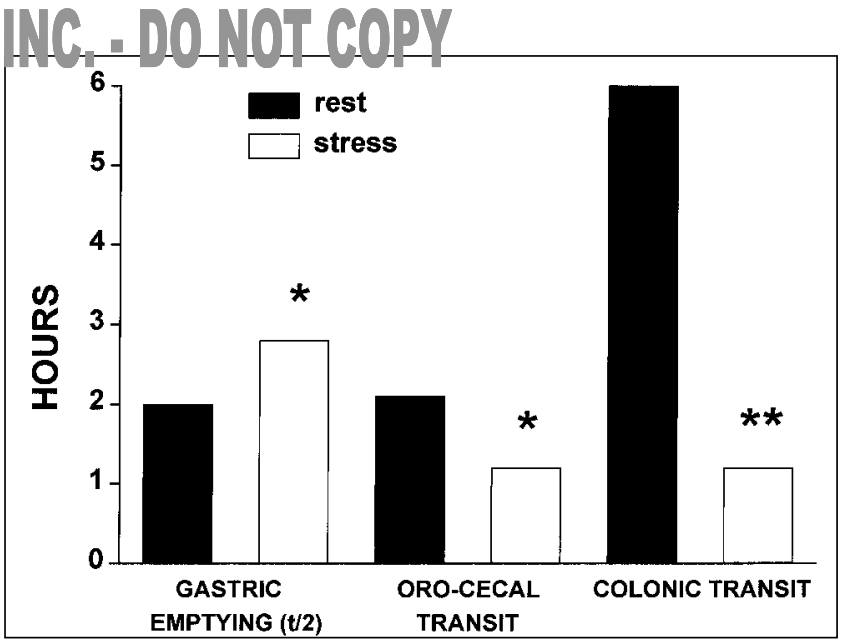

Figure 3) Effects of stress 'passive avoidance' on gastric emptying, orocecal transit and colonic transit in rats. $* P<0.05 ; * * P<0.01$. Reproduced with permission from reference 23

pathology. Indeed, the cold exposure stress test resembles the cold water immersion test used in humans, while the restraint, immobilization, acoustic stress and passive avoidance tests mimic some aspects of psychological stress tests used in humans. However, before attempting to speculate on mechanisms in humans, several aspects of animal stress models have to be dealt with. Stress is a complex, organized and coordinated multiorgan response to changes in the normal environment. Different species react differently through mechanisms not yet fully elucidated. A definite stress response may also be model-specific. For example, gastric emptying in animals is inhibited in response to cold restraint, while it is enhanced in response to cold exposure only. It has been postulated that the increase in gastric emptying in response to cold may reflect TRH secretion and stimulation of gastric contractility, while this effect has not been observed in other stress models (30). Moreover, the kinetics of gastric emptying in response to cold restraint have been shown to be multiphasic, with an initial stimulation and finally an actual retardation. The latter observation suggests that different mechanisms are involved over time in response to stress and, consequently, the predictability of a stress response is very difficult. When looking at the effects of a given stressful stimulus on gastric emptying, the type of meal that is administered to animals (liquid versus solid, nutritive versus non-nutritive) must be considered. In this respect, Gué et al (18) clearly demonstrated that cold stress and acoustic stress significantly enhance the emptying of a nutritive meal in mice; no such effect was found with non-nutritive meals.

\section{CONCLUSIONS}

Hans Selye (4) first described the overall mechanisms that are triggered in response to stress as "the general adaptation syndrome". Since then, several autonomic, neurohormonal, behavioural and peptidergic pathways have been proposed to play an important role in stressful conditions. It is recognized that stress induces disturbances in GI motility through activation of specific brain nuclei and neuronal pathways, as 


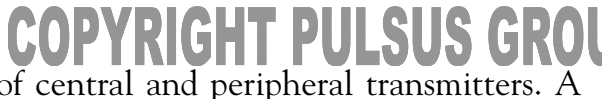
well as secretion of central and peripheral transmitters. A
plethora of neuroanatomical and functional evidence from animal studies indicates that CRF plays a dominant role in stress-induced alterations of motor function in the gut. Notwithstanding its important role, the exact site of action of CRF has not yet been elicitated with certainty. However, most of the effects of CRF have been elucidated with intracerebroventricular injections, suggesting a periventricular site of action of the peptide. Moreover, several lines of evidence suggest that CRF acts in the paraventricular nucleus (PVN) of the hypothalamus. First, CRF immunoreactivity and receptors have been localized in hypothalamic nuclei (31). Second, CRF release in the brain occurs in response to various stressors (32). Third, CRF microinfused into the PVN delays gastric emptying in rats (33). Fourth, microinjection of the CRF antagonist CRF-(9-41) into the PVN abolishes the effects of restraint stress on gastric emptying and colonic transit (33). In light of this investigation, it is likely that the hypothalamus plays a major role in this response.

Most of the studies aimed at determining the effects of stress on GI function did so in acute models; thus, few reports have dealt with the longstanding consequences of stress on gut function. However, from clinical observation, it seems that stress may induce longstanding and possibly permanent changes in gut motility and sensitivity. On close examination, it is often determined that a stressful event (physical or sexual abuse, grief, life event) has occurred at some point in

\section{REFERENCES}

1. Selye H. The Physiology and Pathology of Exposure to Stress. Montreal: Acta Medical Publishing, 1950.

2. Osler W. Experiments and Observations of Digestion. New York: Dover Publications Inc, 1833:1-280.

3. Thompson DG, Richelson E, Malagelada J-R. Perturbation of gastric emptying and duodenal motility through the central nervous system. Gastroenterology 1982;83:1200-6.

4. Selye H. Syndrome produced by diverse nocuous agents. Nature 1936;138:32.

5. Harris GW. The induction of ovulation in the rabbit, by electrical stimulation of the hypothalamo-hypophysial mechanism. Proc R Soc Biol Sci 1937;122:374-94.

6. Guillemin R, Rosenberg B. Humoral hypothalamic control of anterio pituitary: a study with combined tissue cultures. Endocronology 1955;57:599-607.

7. Vale W, Spiess J, Rivier C, Rivier J. Characterization of a 41-residue ovine hypothalamic peptide that stimulates secretion of corticotropin and $\beta$-endorphin. Science 1981;213:1394-7.

8. Rivier J, Spiess J, Vale W. Characterization of rat hypothalamic corticotropin-releasing factor. Proc Natl Acad Sci USA 1983;80:4851-5.

9. O'Brien JD, Thompson DG, Day SJ, Burnham WR, Walker E. Pertubation of upper gastrointestinal transit and antroduodenal motility by experimentally applied stress: role of beta-adrenoreceptor mediated pathways. Gut 1989;30:1530-9.

10. Frexinos J, Staumont G, Delvaux M, Fioramonti J, Buéno L. Influence of cold water stress on colonic myoelectrical spiking activity in irritable bowel syndrome patients. In: Libbey J, ed. Stress and Digestive Motility. London: John Libbey Eurotext, 1989:109-11.

11. Thompson DG. Gastric emptying and intestinal transit in pain stress. In: Libbey J. Stress and Digestive Motility. London: John Libbey Eurotext, 1989:75-83.

12. Mcrae S, Younger K, Thompson DG, Wingate DL. Sustained mental stress alters human jejunal motor activity. Gut 1982;23:404-9.
INC, DO NOT COPY

the patient's life, and from then on, chronic and persistent changes in gut function have occurred. It is likely that stress induces peripheral and/or central plastic changes in the neuropeptidergic network regulating gut motility. In this regard, Collins et al (20) provided animal evidence of stress-induced, not acutely reversible, changes in the fundamental properties of isolated enteric smooth muscle cells. However, controlled human studies are required to define further these so-called permanent effects of stress on gut function.

Research on stress and its effects on gut motility has to deal with significant pitfalls. First, animal models using different methods and species may be associated with different responses. Second, different stressors, and probably magnitudes, of the same stress in the same species may be associated with different responses though activation of a particular neural circuitry and mediators. Third, acute effects are not easily distinguishable from more chronic and perhaps permanent or plastic changes. Extrapolation from animal observations to humans is difficult to achieve, and experimental paradigms in humans provide observations that have to be interpreted cautiously. Notwithstanding the above considerations, a wealth of mechanisms and responses have been described so far and will influence further directions for investigation. Consequently, it is likely that, in the near future, specific pharmacological and psychotherapeutic avenues will be developed to modulate and counteract the effects of stress on gut dysmotility.

13. Delis C, Walker EA, Castillo FD, et al. The effects of psychological stress and an opioid agonist on postprandial motor activity in the human small bowel. Neurogastroenterol Motil 1994;4:169. (Abst)

14. Erckenbrecht JF. Noise and intestinal motor alterations. In: Bueno L, Collins S, Junien J-L. Stress and Digestive Motility. London: John Libby Eurotext, 1989:93-6.

15. Bassotti G, Imbimbo BP, Gaburri M, Daniotti S, Morelli A. Transverse and sigmoid colon motility in healthy humans: effects of eating and of cimetropium bromide. Digestion 1987;37:59-64.

16. Almy TP. Experimental studies on irritable colon. Am J Med 1951;10:60-7.

17. Williams CL, Villar RG, Peterson JM, Burks TF. Stress-induced changes in intestinal transit in the rat: a model for irritable bowel syndrome. Gastroenterology 1988;94:611-21.

18. Gué M, Fioramonti J, Buéno L. Influence of Different Stressors on Gastric Emptying in Mice and Rats, 13th edn. London: John Libbey Eurotext, 1989:133-9.

19. Gue M, Fioramonti J, Bueno L. Comparative influences of acoustic and cold stress on gastrointestinal transit in mice. Am J Physiol 1987;253:G124-8

20. Collins S, Vermillion D, Blennerhassett P, Randall B. The effects of repeated acoustic or hypothermic stress on smooth muscle and enteric nerve function in vitro in the rat; a model for studying hyperresponsiveness in irritable bowel syndrome. In: Libbey J, ed. Stress and Digestive Motility. London: John Libbey Eurotext, 1989:151-5.

21. Koo MWL, Ogle CW, Cho CH. The effect of cold-restraint stress on gastric emptying in rats. Pharmacol Biochem Behav 1985;23:969-72.

22. Enck P, Merlin V, Erckenbrecht JF, Wienbeck M. Stress effects on gastrointestinal transit in the rat. Gut 1989;30:455-9.

23. Enck P. A novel stress model to investigate stress effects on gastro-intestinal transit in the rat. In: Libbey J, ed. Stress and Digestive Motility. London: John Libbey Eurotext, 1989:165-7.

24. Bueno L, Fioramonti J. Effects of corticotropin-releasing factor, 
corticotropin and cortisol on gastrointestinal motility in dogs. Peptides 1986;7:73-7.

25. Garrick T, Stephens R, Yang H, Weiner H, Taché Y. TRH and CRF injected into the brain have opposite effects on gastric contractility in the rat. Libbey J, ed. Stress and Digestive Motility. London: John Libbey Eurotext, 1989:169-70.

26. Garrick T, Veiseh A, Weiner H, Tache Y. Corticotropin releasing hormone (CRH) acts centrally to suppress gastric contractility. Gastroenterology 1987;92:1400.

27. Taché Y, Garrick T, Raybould H. Central nervous system action of peptides to influence gastrointestinal motor function. Gastroenterology 1990;98:517-28.

28. Tache Y, Maeda-Hagiwara M, Turkelson CM. Central nervous system action of corticotropin-releasing factor to inhibit gastric emptying in rats. Am J Physiol 1987;253:G241-5.

29. Peeters TL, Gue M, Depoortere I, Vantrappen G, Bueno L.
ING , DO NOT COPY

Postprandial hormonal status and gastric emptying in stressed dogs. Dig Dis Sci 1989;33:485. (Abst)

30. Arancibia S, Tapia-Arancibia L, Assenmacher I, Astier H. Direct evidence of short-term cold-induced TRH release in the median eminence of unanesthetized rats. Neuroendocrinology 1983;37:225-8.

31. De Souza EB. Corticotropin-releasing factor receptors in the rat central nervous system: characterization and regional distribution. J Neurosci 1987;7:88-100.

32. Haas DA, George SR. Single or repeated mild stress increases synthesis and release of hypothalamic corticotropin-releasing factor. Brain Res 1988;461:230-7.

33. Monnikes H, Schmidt BG, Raybould HE, Taché Y. CRF in the paraventricular nucleus mediates gastric and colonic motor response to restraint stress. Am J Physiol Gastrointest Liver Physiol 1992;262:G137-43 


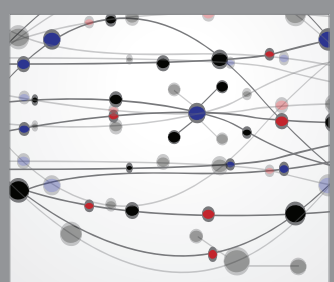

The Scientific World Journal
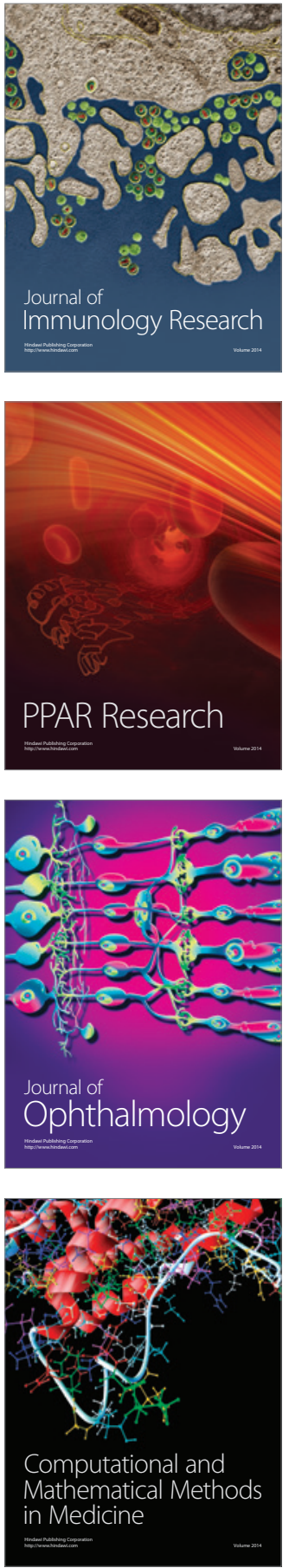

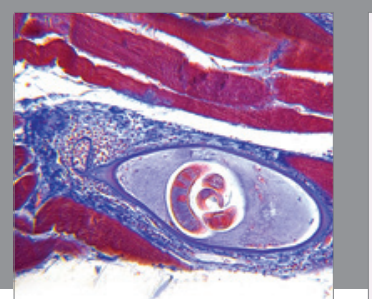

Gastroenterology Research and Practice

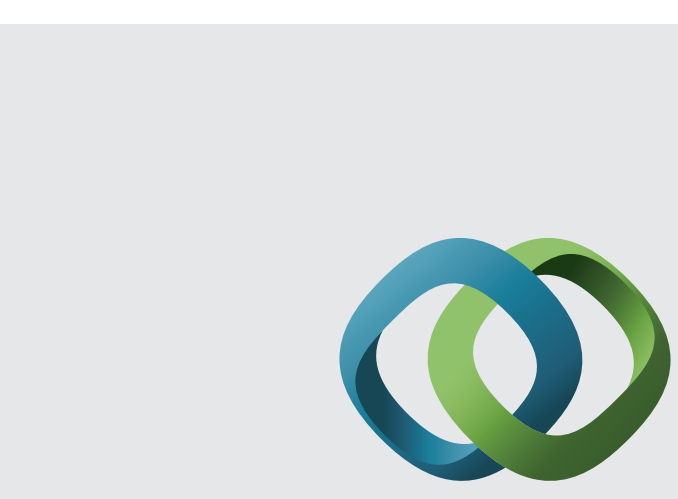

\section{Hindawi}

Submit your manuscripts at

http://www.hindawi.com
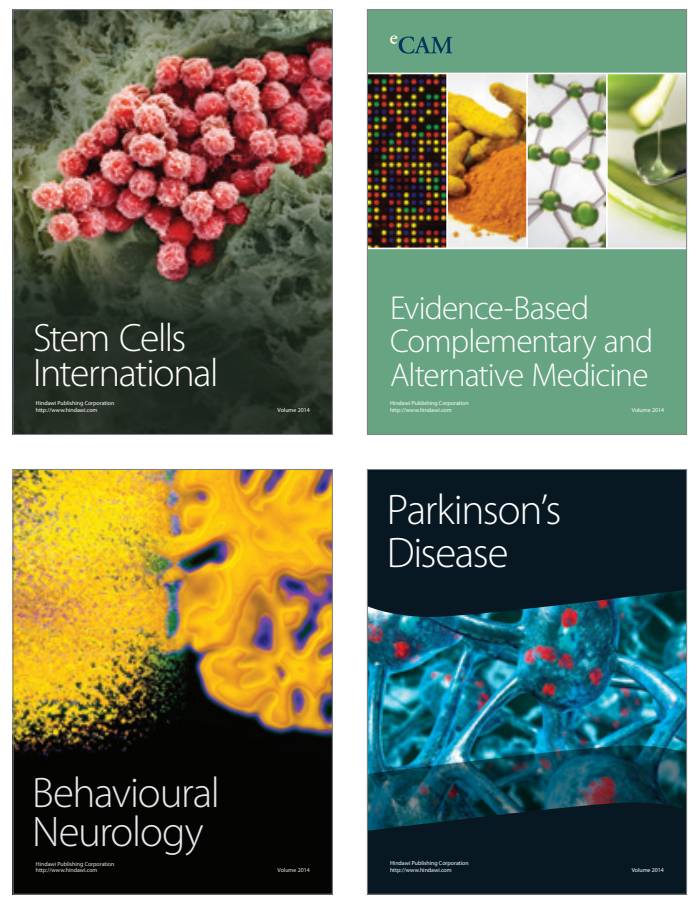
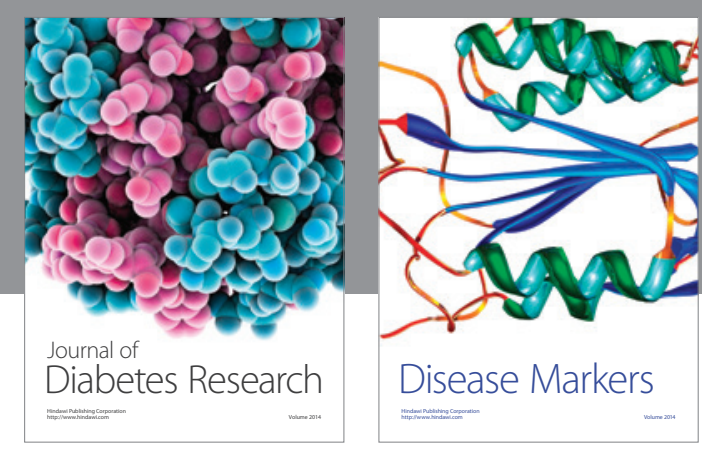

Disease Markers
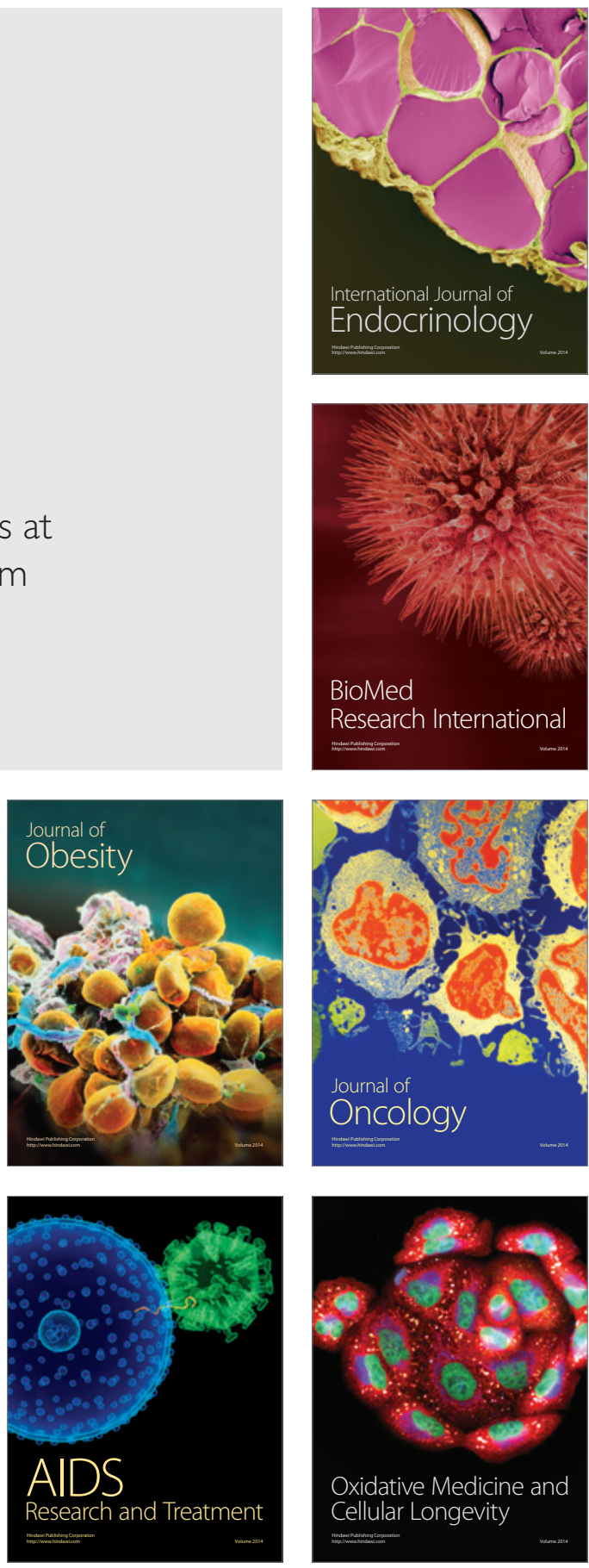